

ISSN : $2302-1590$

E-ISSN: $2460-190 X$

\title{
ECONOMICA
}

\author{
Jurnal Program Studi Pendidikan Ekonomi \\ STKIP PGRI Sumatera Barat Vol.8 No.1 (28-39)
}

\section{THE SOFSKILL MODEL FOR PREPARING GRADUATES WITH COMPETITIVENESS IN REALIZING SOCIETY 5.0}

\author{
By \\ SUWATNO ${ }^{1)}$, ARMIDA. $\mathbf{S}^{2)}$ \\ ${ }^{1)}$ Universitas Pendidikan Indonesia (UPI) Bandung \\ Email: suwatno@upi.edu \\ ${ }^{2)}$ Universitas Negeri Padang \\ Email:mimiasriel@gmail.com \\ Submited: 2019.09.18 Reviewed: 2019.10.18 Accepted:2019.10.29 \\ https://doi.org/10.22202/economica.2019.v8.i1.3602
}

\begin{abstract}
The 4.0 industrial revolution causes disruption or disruption not only in the field of business models, but also the labour market in the next five years with enormous changes. Not after the hustle bustle of the 4.0 industrial Revolution, which is accompanied by the development of the disruption era, suddenly the emergence of the concept of realizing Society 5.0. In this concept, man will play a bigger role with big data transformation into a new wisdom that ultimately increases human capacity to, opening opportunities for humanity to achieve meaningful life, which will Improve the live, and the way we work.

Rapid changes in the workplace as a result of globalization and revolution in technology and other disciplines demanded anticipation and revitalization including the field of education in preparing a reliable graduate of the working as of market. In this era, the development of education enters a very important time, not only in providing quality and optimal services, but also a challenge for education organizers is able to be accepted graduates in the world of work With the level of competition between domestic and foreign universities that quality in accordance with global career standards, but the problem until now occurs disparity between the needs of work market with the skills Prepared by our higher education system.

This research aims to make the design of students soft skills integrated in every course taught in universities that can be used as an entry point in the achievement of graduates who have a competitive and knowledgeable Global according to the needs of the employment market in the realizing Society 5.0.
\end{abstract}

Jel Classification:

O21; O22

Keywords; Softskill, hidden curriculum, realizing Society 5.0.

C2019 Prodi Pendidikan Ekonomi STKIP PGRI, Padang 


\section{INTRODUCTION}

The fourth Industrial Revolution has been generating enormous changes in various fields of technology and scientific disciplines, including education. We have not fully understood yet of the industrial revolution, but a new concept emerged called society 5.0. In this concept, humans will play a greater role in enhancing human capabilities for the achievement of meaningful life by transforming the way they live, and the way they work.

The effects of globalization and revolution in the various disciplines require some kinds of anticipation and revitalization including in education field. The implications are in line with the paradigm change in worklife which also becomes the challenge for education providers. In this era, the revitalization of education is not only required to be able to provide a quality and optimal services, but it is also challenged to be able to result competitive graduates in accordance with career standards needed in the future. The coming employees have to be able to adjust or harmonize themselves with the skills needed. Hence, universities have to prepare their graduates with the competencies required so that they are not separated from the real worklife.

In the real worklife, the graduates are expected to be high competent. They are required to have some abilities in term of technical aspects and good attitudes. In today competition, the labor market is demanded to possess professionalism and managerial skills. This paradigm tranformation has made every company and government agency accept college graduates, not only based on hard skills but also soft skills. In adition to intellectual intelligence (IQ), emotional intelligence (EQ) is also very necessary, especially the way to manage themselves and other people (Waryanti, 2011).
Today, the demand for adequate soft skills from the industrial world is much higher. In the other hand, the real student's environments (social and cultural) currently tend to be colored with permisifism, consumerism and instant culture. This fact is supported by data from several study programs of universities around West regions in 2015-2018 and the advice of Prof. Dr. Agus Rahayu MS (2015), the accreditation assessors of BAN PT, that lead to the conclusion that the soft skill development will be more productive if the activities are more focused and intensified through the curriculum.

The relationship between soft skills and hard skills between business/industrial world and learning program prepared by universities can be seen from the ratio of the necessity of soft skills and hard skills in the business and industrial world with the ratio of soft skill's learning given in the education curriculum. This is supported by some findings of the study (Illah Sailah in Armida, 2016).

Several studies (Slamet, 2010, Putra, 2009, Endang, 2008, Ginanjar, 2002) shown an irrelevancy between the sofskills prepared by Universities with industrial world. This discrepancy is caused due to the differences of viewpoints about hard skills and soft skills between Universities with industrial world, include: 1) the ratio of the necessity of soft skills and hard skills in industrial world is inversely proportional to its development in universities. The success in the real worklife is $80 \%$ determined by mind set (soft skills) and $20 \%$ is determined by technical skills (hard skills). But in the practice of our current education system especially in universities, the portion of soft skill's development is only given $10 \%$ of the curriculum in the average, while $90 \%$ of it contains hard skills; and 2) the high competent graduates are whose high GPA and on time ( $<4$ years) as well as short waiting times to get a job. In the other hand, 
the business/industrial world states that high competent graduates are whose the ability in technical aspects and good attitude, as well as the strength of every graduate to have commitment to the agreement he made at the first job.

The demand of relevance between the education world and industrial world suggests that university graduates have to possess a number of competencies that can be demonstrated in the workplace. Therefore the university graduates must be equipped with soft skills learning program that is integrated in the lecture activity process (Muntafi, 2016
). According to Sailah (2007), the content of soft skills in national educational curriculum is only $10 \%$ while the hard skills is $90 \%$. It is inversely proportional to the needs of workforce. As a result, the discrepancy happens between workforce' demand and university's softskills (Armida, 2018). Based on this phenomenon, the researcher wants to describe how the preparation of university's graduates in entering competition in the era of society 5.0 based on softskills integrated in learning process.

This research used the following framework:

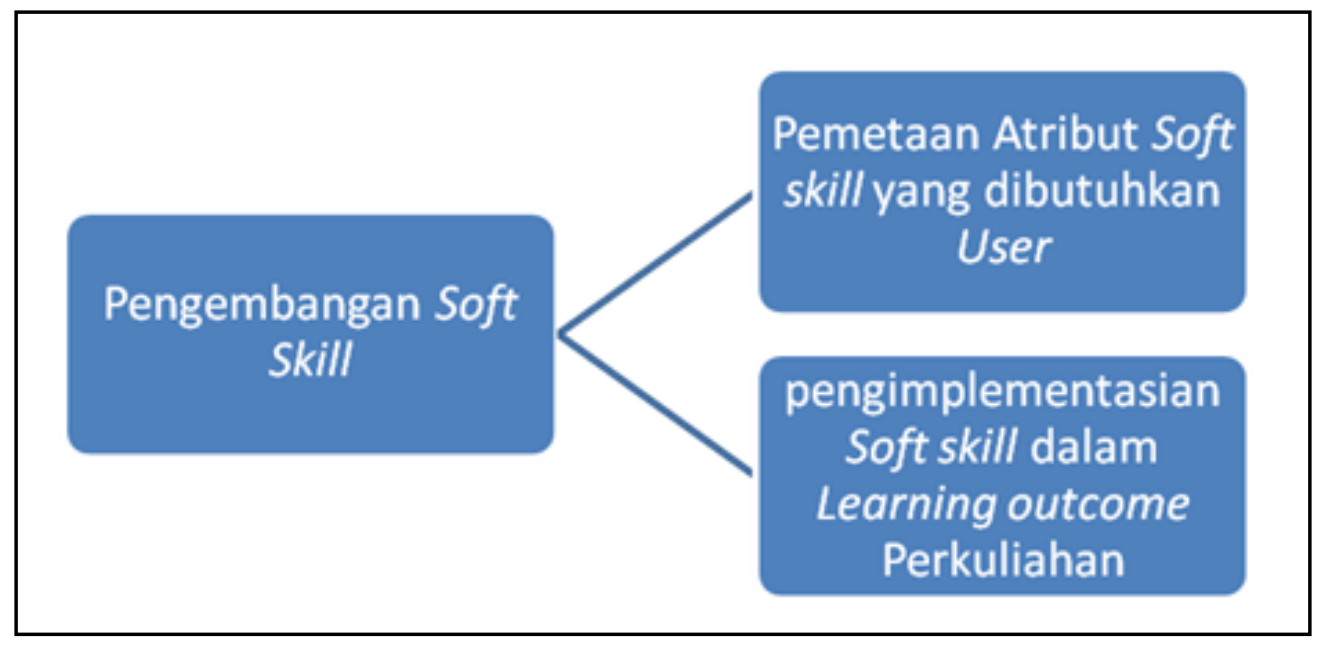

Figure 1. Framework

\section{METHODS}

This research combines quantitative and qualitative approaches. According to Branen in Kerlinger (1995), the merging of the two methods will provide a deeper understanding of objects related to human attitudes and behavior. Specifically, the data analysis performed using a mixed method of the Research and Development with three cycles: (1) Identify or mapping the softskill's attributes in accordance with the end user's needs to university's graduates (2) Analyze the softskill's element prepared by colleges in learning outcomes (3) Recommend a policy of soft skill's learning model in universities to prepare competitive graduates in the era of society 5.0.

The respondents of this research are alumni, business/industrial world, state owned enterprises (BUMN), banking as well as government agencies that become the workplaces or internships for the university's students in Western regions of Indonesia.. The research approach used is juridical sociological with primary and secondary data processing. The secondary data was taken from each Faculty of Universities located in Western region as well as other related institutions as the end users. Besides, the researcher also took the data from some literature and government regulations. 


\section{RESULTS AND DISCUSSION}

a. Disparity of the required workforce's skills with the prepared university graduate's skills.

The results of this study concluded that 23 softskill's attributes classified into 7 types of abilities based on the BAN PT standards and the tracer study of several universities that were used as respondents of this study, shown that almost $82 \%$ of university's graduates in western region had loyalty at their first jobs. It is indicated by a little number of first jobs used as a temporary jobs. College graduates in the western regions also wanted to develop themselves and tended to obey to the rules imposed by the company. However, they tended to be less confident, less communicative, doing bad work habits and less able to think analytically, difficult to work together, less able to write well in Indonesian and English, difficult to adapt and less creative. These findings are series of non-technical competencies that are often overlooked in college's learning.

If it is correlated with Ila Sahila's research findings, stated that the graduate's competence in the workplace is divided into two aspects. First, the technical aspects related to the background of expertise needed in the workplace. Second, non-technical aspects included motivation, adaptation, communication, teamwork, problem solving, stress management and leadership and so on . Each end user in industrial world tended to require a series of different technical and non-technical competencies for university's graduates to be recruited, but in general nontechnical competencies (softskills) are needed more than technical competencies (hard skills).

This can be seen when hiring employees, a series of non-technical capabilities required by the company is a combination of:

1. Confidence
2. Able to work together in teams

3. Able to communicate orally and in writing

4. Analytical thinking

5. Adaptable

6. Discipline

7. Have good leadership

8. Honest, innovative and creative

9. Able to face urgent work

10. Able to work under pressure

11. Have a great sense of services

12. Have initiative with attitude and integrity at work

13. Able to work independently, little guidance

14. Responsible and committed to the work

15. Have motivation and enthusiasm at work

These qualifications are almost similar with what was formulated by the Wolrd Bank, that the skills needed by employers are combination of the following (Word Bank 2013, 2017 and Selingo, 2016, Marmolejo, 2017):

1. Possitve work habits

2. Communication

3. Writing

4. Matemathics

5. English

6. Problem solving

7. Team work

8. Tenacious

9. Creativity

10. Tough

11. Digital awareness

12. Contextual thinking

13. Humility

If this research finding is compared with the demands of end users, it can be concluded that most employers (end users) complained to college's graduates because they have no sufficient skills in terms of selfconfidence, communication skill, work habits, ability to think analytically, teamwork, writing skills both in Indonesian and English, workplace adaptability, and 
creativity. This means that university's graduates generally have no readiness to enter the workforce, especially related with sofskill.

Why is social networking skill more necessary? The reason is simple: providing training to develop skills is much easier than character building. At the moment the hard skill approach starts to be abandoned. It is indicated that the job vacancy advertisings of various companies more prefer to require soft skills such as team work, communication skills and interpersonal relationships as job requitment. Even when recruiting employees, companies tend to choose candidates whose better personalities even though their hard skills are lower. This shows that hard skills are an important factor in working, but one's success in working is usually more determined by good soft skills .

The next question is which softskill attributes has been prepared by universties in western region? Several universities have compiled curriculum based on KKNI standards that contains attitudes in learning outcomes as a reflection of moral character, faith, honesty and modesty, and performance characters contained in general skills that are logical and independent, responsible, able to make decisions but do not include the required performance characteristics such as communicating effectively, critical thinking skills, skills to respect others, work attitudes and motivation, hard work, confidence, tough, resilience, and persistence.

Elfindri et al (2012) mentioned that in the practice of employee's selection processes, companies generally do filter based on the aspects of logical and analytical thinking skills at the early stage. Then proceed with the selection of character and work attitude, while in the final selection process, new selection is based on the technical and academic abilities of the prospective employees. Especially for the interview selection process, this process is very strict with soft skills, namely effective communication skills, critical thinking skills, skills to respect others, attitudes and work motivation. Even when recruiting employees, companies are more likely to choose candidates whose better personalities even though their hard skills are lower. This is in line with the Lickona's theory of success triangle (in Putri, 2012). 


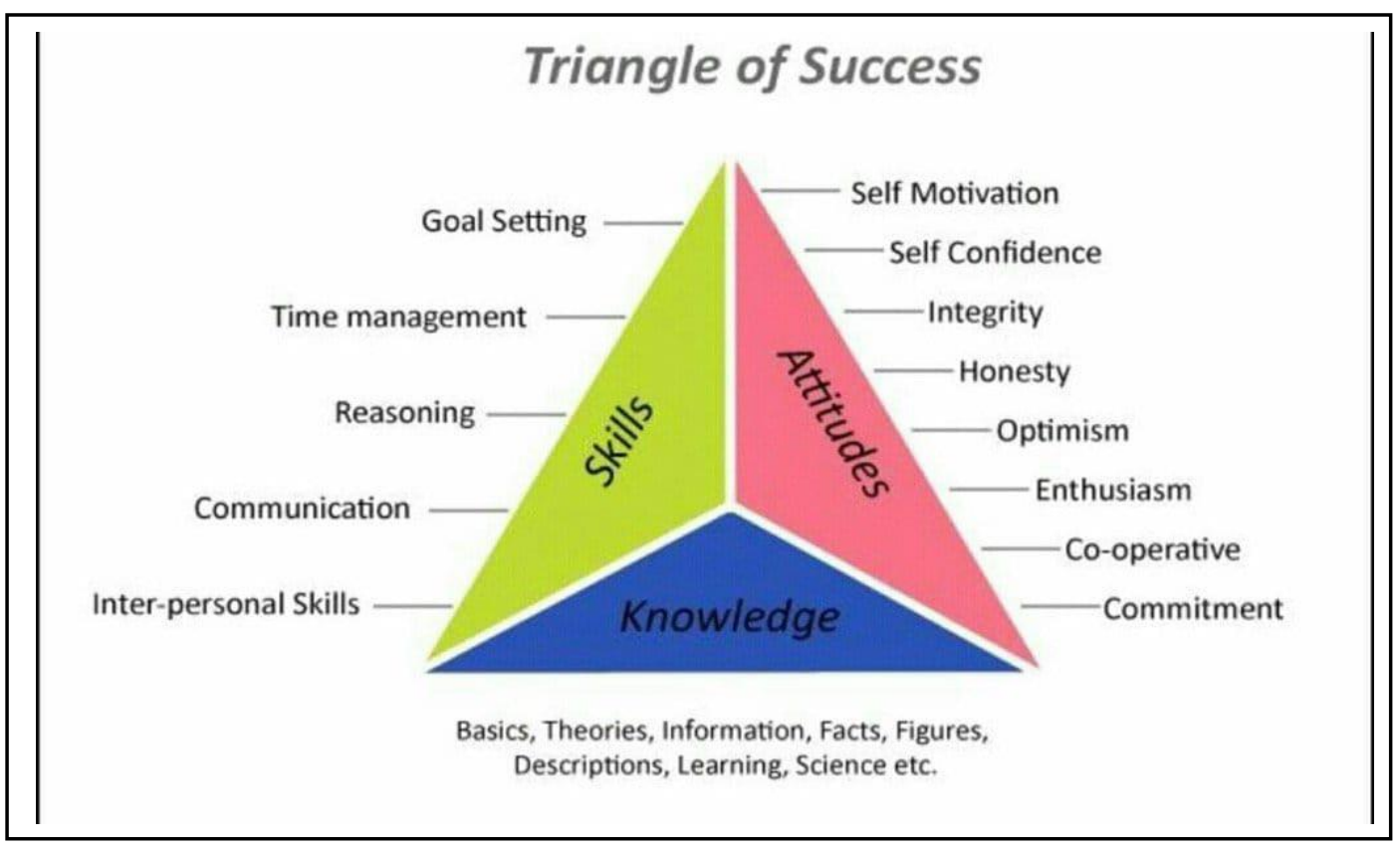

Figure 2 Triangle Of Success

Based on the interviews with the users, stated that today the paradigm of worklife has changed. In the past, companies used to do administrative selection and IQ test, but now with the GAP formula, the users need worker's candidate whose good general knowledge, good attitudes and the last are academic performance and test scores . The results of the study concluded that there was a disparity between the preparation of university's graduates with a combination of end-user needs in the worklife. This indicates that the universities in west region have not been able to harmonize the needs of users .

Mc Clelland in his book as quoted by Irma (2007) argues that self-confidence, adaptability, leadership and the ability to influence others are the realm of soft skills which are major factors of young executives's success in the world. Universities as the institutions resulting worker's candidates should adapt the paradigm shift of graduate's skills.

b. Softskill learning model in preparing competitive graduates.

One of the implementation of university autonomy in adapting the end user's needs is through a redefinition of the curriculum, because the curriculum development supported by the system and learning methods as well as adequate means will effectively bridge the need's disparities. For this reason, the universities in western region have to be able to maintain their learning outcomes in accordance with the demands of the workforce in the future.

The recommended model of softskill learning in universities refers to the framework of the 21st century education projection concept as cited by Anis Baswedan's video (2018 ), as a following scheme: 


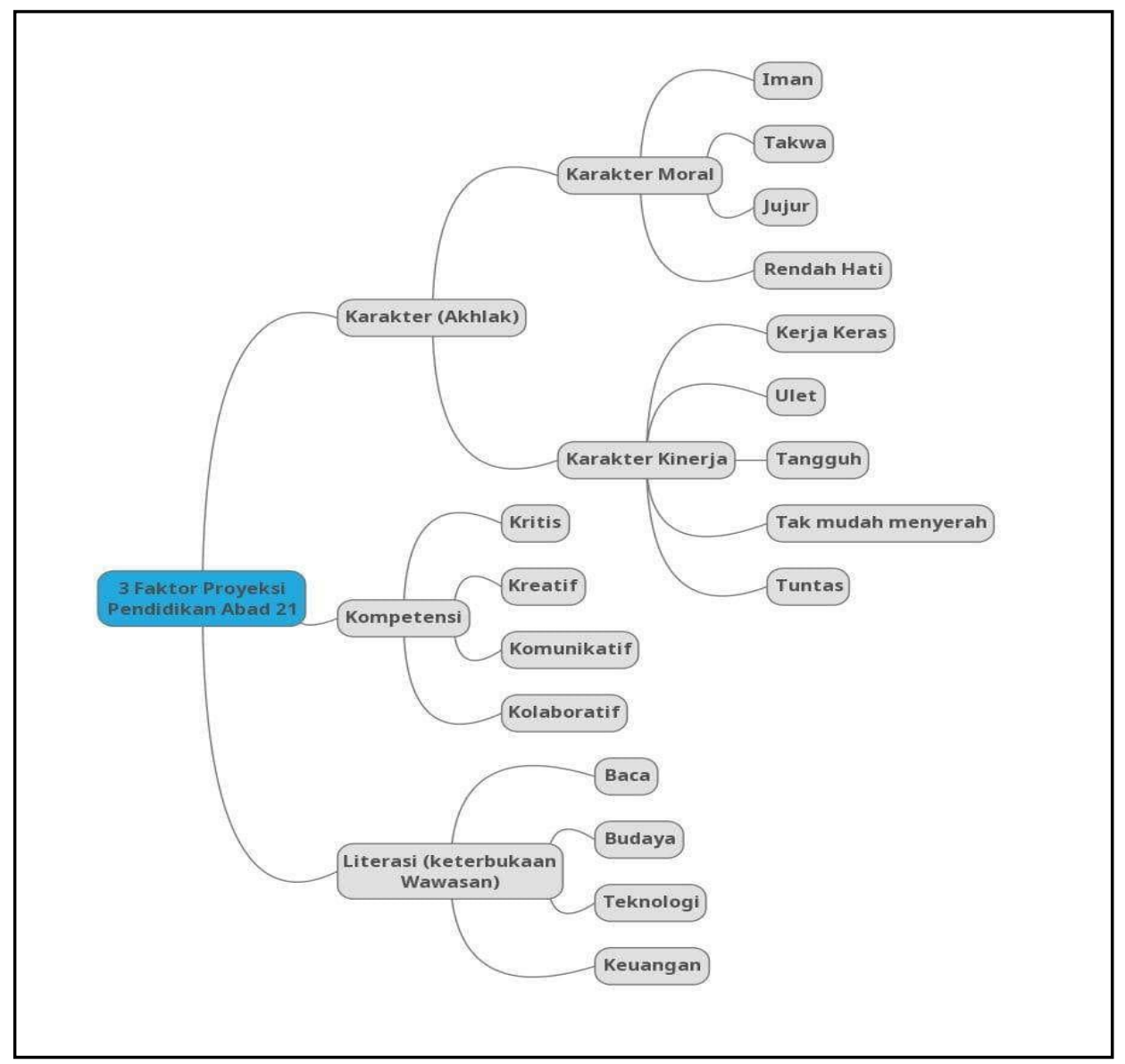

Figure 3 Scheme Of 21st Century Education Projection

To successfully generate ideal graduates whose balance skills between hardskills and softskills, universities need to create a conducive academic climate with the development of characters, competences and literacies. This is in line with the research findings according to Illah Sailah (in Armida,
2016). In adition to intellectual intelligence, emotional intelligence (EQ) is also very necessary, especially the way to manage themselves and other people (Waryanti, 2011). There are three components in forming good character which should be contained in the university's curriculum. 


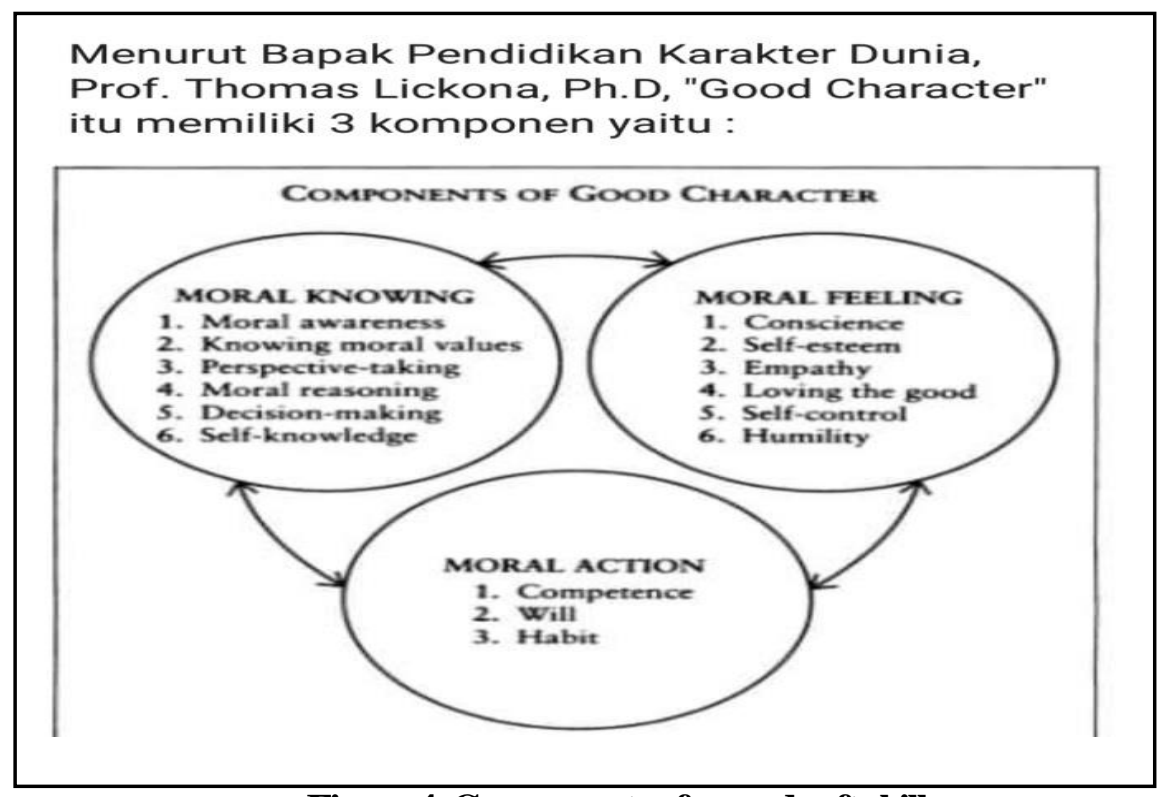

Figure 4. Components of a good soft skills

Various literatures explain that several alternatives in carrying out education and softskills training are integrated in the following curriculum: (Heri, 2014)

1. The content of softskill material is an integral part of the curriculum.

2. Course subjects of character building should to be delivered since 1st to 5th semester and required to pass with non credits.

3. Integrate the evaluation of student's softskills with the learning evaluation system in the student's portfolio, or through extra curriculum approach where the student's softskills are trained in various forms of integrated activities in student activity units (UKM) and existing student organizations.

Integrating softskills contained in the achievement of entire course curriculum, which means that is contained as an element in the whole course subjects (hidden). It need not be part of certain subject, but has always to be delivered as additional competence in every teaching and learning activity (Illah Sailah, 2008: 37).

"Hidden Curriculum is the broader concept of the which the informal curriculum is a part". Hidden curriculum is more effective in building softskills because it can make the learning process more interesting and enjoyable. According to Illah Sailah (2008: 37), the development of softskills is only effective if carried out by means of transmission.

Elfindri, Ichsan, Putri et al $(2012,2015)$ stated that the strategy to apply softskills needed to be integrated into the learning process and extracurricular activities as well as inside the school dormitory, of course, if the school has a dormitory.

Some universities in the western region have implemented this approach by requiring students to be active in extra-curricular activities throughout their studies. At the end of their studies, before taking a thesis examination, students are required to submit a self-evaluation made under the supervision of an academic supervisor. The self-evaluation that has met the requirements is prerequisites for the thesis examination.

Some universities in west region have also had a policy to create an atmosphere that is appropriate for developing student's softskills and hardskills, for example through competition programs with credit system which becomes a requirement to get Surat Keterangan Pendamping Ijazah (SKPI) and Surat Keterangan Prestasi Mahasiswa (Sipresma) as additional recommendation for users (companies). 
The softskills will be more effectively transmitted and proven directly in practice. In other words, students have to obtain softskills on campus, either through individual learning or in an integrated manner with other subjects, as well as interactions in real campus life.

Academic atmosphere became a field of good learning experience for students, by seeing, feeling, and directly proving good practices (best practice) when interacting with fellow students, employees, lecturers, and institutional leaders. Therefore, the institution whose poor academic atmosphere will be the example of bad soft skills for students, and vice versa, because attitude and behavior of teachers, employees, leaders in their daily campus activities will affect the quality of their learning by doing.

There are several ways that can be taken to develop soft skills, first through the process of learning by doing, second is to attend training and seminars offered by many institutions. The trainings are mostly targeted program development of human resources that are formed by individual or by cooperation with companies through internships, the third is training and learning programs in universities because they are responsible for accountabilty.

Soft skills education and training in universities can be carried out with several approaches: curriculum, extra-curriculum, and the creation of academic atmosphere. These three approaches are the basic character for the philosophy of the Real Campus.

In this research, the model of graduate's quality improvement is suggested to implement a comprehensive, effective and transformative learning system. Furthermore, transmitting softskills such as teamwork, confidence, communicative and assertive skills should also be integrated and developed through student coaching programs. It aims to increase knowledge (cognitive), attitude (affective) and skills (psychomotor) to generate added values in order to increase the competitiveness of graduates through empowering hidden curriculum in universities.

The involvement of the study program in the development of this program through several stages: 1). Preparation of the Study Program in conducting this development begins with a survey of the needs of softskills in the industry. This focuses on the kinds of softskills that will be strengthened for students in accordance with the needs of users. 2) Developing an integrated soft skill in the curriculum with stages:

a. Introduction Stage or Seft Management, at this stage is a phase focusing on fundamental soft skill attributes, such as ability to recognize themselves, their life goals and their environment. The Introduction phase is primarily intended for first-year students (1st and 2nd semesters). The new students need to be adaptive so they can survive in their new environment. This program will make new students able to recognize themselves as well as their environment, so that later they will be able to manage their abilities in an effort to become high quality individuals.

b. Growth Stage or Relationship Building Stage, this stage is mainly aimed to students in the second year (3rd and 4th semesters). At this stage there is a tendency for students to start interacting activities that are more familiar with their environment. With the actualization of their potential, the students are expected to be able to develop themselves into independent and mature people.

c. Network Building Stage (SocialNetworking) or Maturing Stage is mainly aimed to third and fourth year students (5th to 8th semesters). At this stage, students have a deeper understanding to the environment. This is indicated by the mastery for seeking 
information and social networks (social networks) that are quite extensive. At this stage students are more focused on efforts to complete their studies and begin to focus on the work market that they will enter later.

The development of student's softskill is built and carried out in a systematic, comprehensive, integrated and sustainable manner. Systematic means the development of softskills by using a system, namely in the activities carried out involving input, process and output. Comprehensive, namely the development of softskills conducted by the entire academic community among students, educators and education staffs. The limited capacity of the entire community will contribute to the commitment to implement the softskill's development program so that it can proceed as planned. Integrative, i.e. the process of softskill's development is done in stages where stage one and the next stage do not stand alone, but support each other to be able to create synergies that will produce more value. Integration also occurs in implementing softskill's development which is not solely a shared responsibility. Continuous, namely in its implementation, the development of softskills is carried out in stages, starting from the introduction stage, followed by the growth stage and ending with the maturation stage. This continuous phasing is crucial so that the process of developing student soft skills does not overlap or even be overlooked, taking into account the psychological development of students, such as the following model:

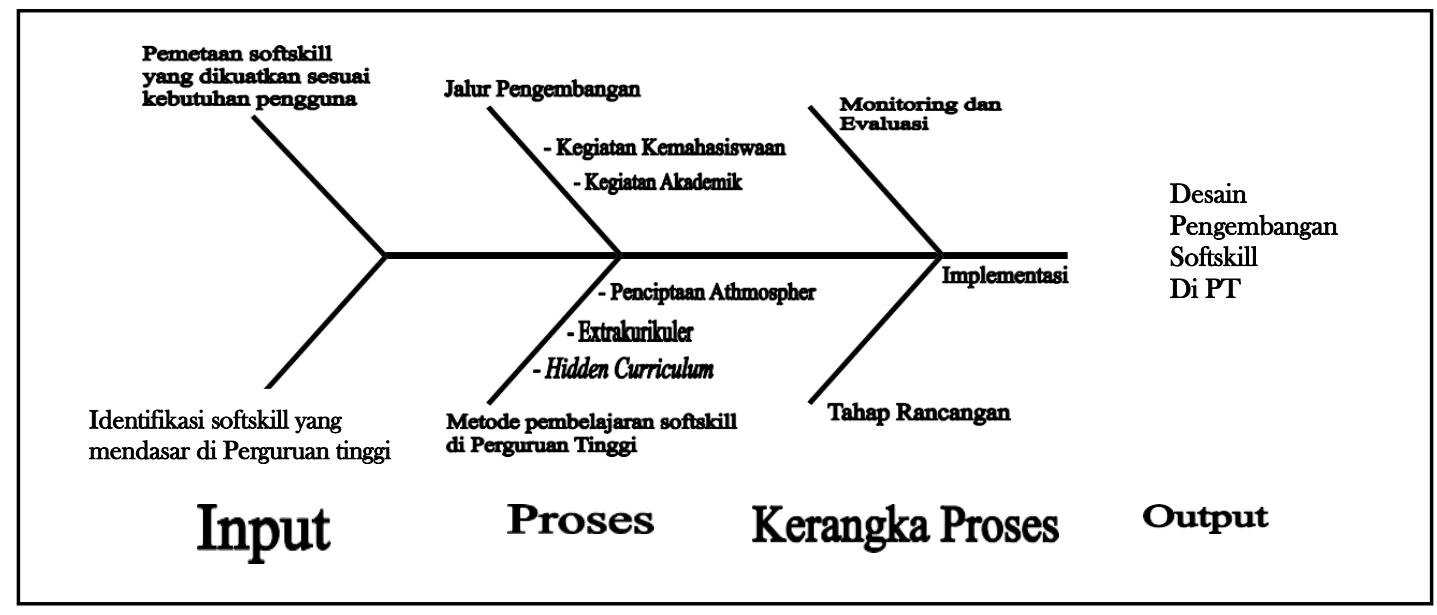

Figure 5 Model Of Softskill Learning Development Stages

\section{CONCLUSION}

The current work market requires a combination of various skills with the preparation of university's graduates. There is a disparity in the preparation of graduates with a combination of end user's needs in the worklife. This disparity makes most employers (end users) complain to college's graduates because they are deemed not to possess adequate skills in terms of selfconfidence, communication skill, work habits, analytical thinking skill, teamwork, writing skills both in Indonesian and English, adaptability and creativity. This makes universities in the western region need to provide all user's needs.

Therefore, the universities in western region should respond the paradigm shift in behavior and action of work market. One of the recommendation is to build conducive academic climate through redefining curriculum content and learning outcome. To 
produce qualified and competitive graduates, a conducive academic climate is needed that forms the ideal individual students whose balanced ability between hardskills and softskills. Student's softskill development is built in such a way and is carried out systematically, comprehensively, integrated and continuously.

The model of quality and competitive development of university's graduates develops softskills through comprehensive, effective and transformative learning system as the added value for graduates. All Universities in western region are expected to integrate softskills as the important element in all course subjects as additional competence in every learning activity.

\section{REFERENCE}

Andika, Basori, Efendi. 2018. Effect of Student Activity in Organizing and Learning Achievement on Job Readiness Students of the Information and Computer Engineering Education Program at Sebelas Maret University. Sebelas Maret University Journal Vol. 4 No. 2, May 2018. Surakarta.

Anis B, Proyeksi pendidikan abad 21, retrived from youtube tanggal 2 September 2018

Armida dkk (2008) Grand disign hidden kurikulum pengembangan softskill mahasiswa, paper in ICEMAL Bandung

Ary Ginanjar Agustian, 2002, ESQ: Rahasia Sukses Membangun Kecerdasan Emosi dan Spiritual, Penerbit Arga, Jakarta

Elfindri dkk, Soft Skills untuk Pendidik, (Jakarta: Badouse Media, 2012),
Endang, S. (2008). Pengembangan Instrumen Soft Skills Mahasiswa Bahasa Inggris. Universitas Negeri Yogyakarta.

Kerlinger FN (1995) Asas-Asas Penelitian Behavioral,Yogyakarta, Gajah Mada, University Press

Kuswara Heri. Materi Seminar Soft Skill Berjudul: "Pentingnya Soft Skill dalam Meraih Karier Gemilang", October 2014, Bina Sarana Informatika

Lickona, Thomas. 1991. Educating for Character: How Our School Can Teach Respect and Responsibility. New York, To- ronto, London, Sydney, Aucland:Bantam Books.

Muntafi', Putri Sari Nurhidayati dan Astuti, Isthofaina. 2016. Kesiapan Kerja Mahasiswa Ekonomi dan Bisnis UMY Menghadapi MEA. Jurnal Manajemen Universitas Muhammadiyah Yogyakarta.

Mourshed, Farrell, \& Barton. (2012). Education to Employment: Designing a System that Works.

Putra S Ichsan, Ariyanti Pratiwi, 2009. Sukses Dengan Soft Skills. Direktorat Pendidikan Institut Teknologi Bandung (ITB)

Putri, Rinella. Artikel berjudul : "Pentingnya Soft Skill". situs:http :// www.vibiznews .com (accessed at 19 januari 2016)

Saillah Illah, (2008) "Pengembangan soft skills dan implementasi KBK serta proses pembelajaran di Perguruan Tinggi 
Santoso Slamet, "Softskills di perkuliahan, qouvadis..?? Integrasi Soft Skill Mahasiwa di Perkuliahan; Langkah letih Pengembangan dan Pendekatan Pendidikan di PT"; 2010, http://www.bisesagroup.com

Rosyiidah, Afiifah Al. 2013. "Pendidikan Karakter pada Classic Fairy Tales". Jurnal Pedidikan Karakter, Tahun III/Nomor 3. h. 252. Yoyakarta: 